\title{
THE INNOVATIVE TOOL FOR SOCIAL HOUSING PROVISION AND MANAGEMENT IN POLAND - SOCIAL RENTAL AGENCIES
}

\author{
Katarzyna Suszynska ${ }^{1, a, *}$ \\ ${ }^{1}$ Poznan University of Economics and Business, Department of Investment and Real Estate, al. \\ Niepodleglosci 10, Poznań 61-875, Poland \\ akatarzyna.suszynska@ue.poznan.pl \\ *Corresponding author
}

Cite as: Suszynska, K. (2017). The innovative tool for social housing provision and management in Poland - Social rental agencies, Ekonomicko-manazerske spektrum, 11(2), 90-102.

Available at: dx.doi.org/10.26552/ems.2017.2.90-102

\begin{abstract}
Although there is a heated debate on the shortage of social housing in Poland, little has been done to mitigate the problem and counterbalance market inequalities. The aim of the paper is to explore the novel tool within social housing policy and management aimed at making access to cheap rental housing easier, i.e. social rental agencies (SRAs) acting as intermediaries between private landlords and vulnerable households. The paper is theory and literature-based. It outlines and researches the concept and features of SRAs as introduced by other European countries. The main research question is to find out whether these institutions should be employed in the process of improving the existing social housing system in Poland. In order to meet the principal objective of the paper, the author: 1) reviews recent housing situation in Poland affecting the need for affordable housing provision, 2) presents definitions of SRAs and provide an overview of their functioning, and 3) makes an attempt to evaluate the possibility to use the tool to expand the existing social housing stock. Although the institutions have long been recognized in many European countries, in Poland SRAs are practically unknown. Only a few non-profit and small-scale initiatives based on SRA model have been observed so far. However, due to the recent promotion of the tool by a non-profit organization Habitat for Humanity, the scale of existing programmes has gained potential to be expanded. As a result SRAs can offer a relatively low-cost solution to address housing needs and enlarge the stock of social housing.
\end{abstract}

Keywords: social rental agencies, social lettings agencies, social housing

JEL Classification: R21, R30, R31

\section{Introduction}

In spite of the great diversity of European social housing systems in terms of rationale, mechanisms and policy regimes, recent tendencies and challenges in the sector appear to overlap across countries. One may observe increasing interest in new social housing provision as shortages of affordable housing in high pressure markets grow and waiting lists swell. (Whitehead \& Scanlon, 2007; Holmqvist \& Turner, 2014; Christophers, 2013) In these conditions, housing actors and funding systems have adjusted to the new environment and some innovative entrepreneurial models have emerged. The focus is on diversifying social housing providers, public private partnerships as well as the development of mixed communities in the 
context of urban regeneration. (Gherkiere, 2007; Tsenkova, 2014) Notwithstanding some similarities in developments of social housing regimes, it is not very likely that there will be an importation of western social housing ideas and practices to Poland. Due to financial constraints, one cannot expect large-scale and fiscally expensive programmes that would considerably enlarge the social housing stock. Instead, a range of different state programmes targeting different types of households emerge. There are likely to be innovative schemes trying to employ private capital and private rental stock for social purposes. This new, multi-channeled approach adheres more to the institutional context of post-socialist societies than historical models of social housing. (Lux, 2016; De Decker \& Pannecoucke, 2004)

According to Lind $(2001,2016)$, the basic criterion for deciding whether the state boasts social housing policy or not, is to check the possibility to quickly rent a flat that is both of decent standard and affordable. In high pressure markets of big Polish cities, this task is demanding, or even impossible to complete. Rents in apartments available on the open market are too high for low- and even medium-income households, while thresholds for accessing the municipal stock are stringent. Social housing in Poland is used as a safety net -it is mainly publicly owned, managed under a rent control regime and allocated administratively to households according to social and economic criteria. Therefore, it is vital to search for new ways of providing rental apartments for vulnerable households. The aim of the paper is to explore the novel tool within social housing policy aimed at making access to cheap rental housing easier, i.e. social rental agencies (SRAs), sometimes referred to as social letting agencies (SLAs). These are understood as institutions mediating between private landlords and people in housing need. Although they have long been recognized in many European countries (e.g. Belgium, Great Britain, France, Italy), in Poland SRAs are practically unknown. Only a few non-profit and small-scale initiatives based on SRA model have been observed. However, due to the recent promotion of the tool by a non-profit organization, Habitat for Humanity, the scale of existing programmes could be expanded, and as a result SRAs could offer a relatively low-cost solution to address housing needs and enlarge the stock of social housing.

\section{Literature review}

There is a vast body of literature on European post-socialist countries that have opened up their housing systems to the free market. Under the systemic transformation, states have withdrawn from housing provision and maintenance anticipating that private developers and owners would take on the new challenge. Investing in social housing or decreasing social inequalities have become an obsolete notion. (Hegedus et al., 2014; Lowe \& Tsenkova, 2003; Van der Heijden, 2013; Soaita, 2015) With give-away privatization reaching 99\% of the market value, public housing has quickly and considerably shrunk in most post-socialist states leading to the creation of "super owner occupied nations" like in many Western European countries. (Lowe \& Tsenkova, 2003; Malpass, 2008) Moreover, few attempts to establish new affordable housing policies for households that could not cope with free market conditions have been implemented in a very specific manner. Lux (2016) argues that almost all attempts at reinventing social housing during the economic transformation process have proved to be both unsustainable in the long-term and often ended up in further enlargement of homeownership. (Przymenski \& Oliwa-Ciesielska, 2014)

The strong preference for a market-driven path to owning (or renting) homes has led to the situation where almost half of the Polish society struggles with difficult housing conditions, more than $15 \%$ of whom cannot meet their housing needs in a way that conforms to basic norms and standards. (NIK, 2012; Strączkowski \& Suszynska, 2012) In Poland, the responsibility for 
satisfying housing needs is devolved to the local level. Thus, local self-governments are burdened with the duty to provide public housing for low income and disadvantaged households, manage the public stock, and provide housing allowances to destitute households. However, they perform poorly in doing so, mainly due to three basic conditions:

a) dwindling financial resources from the state. This impedes the possibility to produce new public housing or restore the existing stock. The resources have been curbed considerably after liquidation of The National Housing Fund in 2009. The Fund provided public and non-profit housing actors with preferential loans amounting up to $70 \%$ of investment costs for the construction of rental housing,

b) inefficient system of municipal housing management (further privatization at a discount price, open-ended contracts for social housing, generous rent reductions, considerable rent arrears). Since 2007 local governments have been forced to award full compensation for households evicted from housing with court judgement, yet who are still on waiting lists,

c) municipalities' tools for providing affordable housing are restricted to municipal housing stock and housing allowances. (Żołędowski et al., 2015)

Taking into consideration the above mentioned imperfections of the system, it is clear that the need for more affordable housing is compelling - experts estimate the number at approximately 30 thousand social dwellings (150 thousand municipal dwellings and 150 thousand units in the stock owned by social housing associations called TBS). (MuziokWęcławowicz, 2017) Therefore, it would be advisable to follow the pattern of many European countries that have incorporated various actors representing the private sector into their affordable housing provision. International experience shows that there has been a long tradition of public-private interventions across developed countries since the 1970s. Government interference has encompassed two categories: demand-side (rent allowance system used to supplement rents within the private rental sector), and supply-side interventions (subsidy programs based on capital grants, reduced interest rates, loosening building regulations). The latter are supposed to increase the supply of private rental flats and should by definition mark down rents. (Hegedus et al., 2014) Social rental agencies are a mix of demandand supply-side intervention. Designed to act as mediating agents between private landlords and people in housing need, they address the problems of both owners of vacant apartments, and low-income tenants that would otherwise face barriers accessing housing. (De Decker, 2012) The author believes that such cooperation between private and public housing actors within social housing policy may turn out to be highly beneficial for each party involved. The landlord sheds responsibility for maintenance and administering the rental contract. He/she also receives a long-term guarantee of stable rental incomes. Tenants on the other hand profit from affordable rent rates, long duration of contracts, and decent housing standards. Often, they are also offered social assistance in job search, overcoming addictions or solving other problems. Social rental agencies function in many European countries, yet they are best rooted in Belgium and England. A few initiatives similar to SRAs have already been taken up in Poland, yet they have never been institutionalized. This is the result of the gap in social housing policy that does not incorporate the private rental stock into realization of social goals. (Lis, 2006) The debate about changes becomes heated thanks to the non-profit organization Habitat for Humanity Poland (HHP) that has recently conducted a project aimed at promoting SRAs as a potential tool for assisting housing policy goals. The conferences and meetings on SRAs organized by HHP for local self-governments and other housing actors attract a lot of interest. Yet the path to a broad employment of this innovative tool seems to be long and curvy. 


\section{Methodology and research procedure}

The paper is theory and literature-based. It outlines and researches the concept and features of SRAs as introduced by selected European countries. The main research question is to find out whether these institutions should be employed in the process of improving the existing social housing system. The overarching technique of researching the subject issue is the monographic method as described by Apanowicz (2003). It encompasses a detailed and at the same time comprehensive description of the quantitative and qualitative nature of the problem, based on various types of materials and sources. Moreover, the document analysis and literature critique methods are used. They allow for thorough recognition and evaluation of the existing body of literature, pointing at achievements and deficiencies in the area. Due to the complex socioeconomic nature of the subject housing sector and lack of conceptual frame to be applied while conducting the research procedure within the field, the explanation of the tackled problem is carried out with the use of cognitive description method. It entails obtaining, processing and classifying data along with conducting a cause-and-effect analysis of phenomena. (Harvey, 1969) On the basis of the aforementioned methods, in order to meet the principal objective of the paper, the author:

1) reviews recent housing situation in Poland affecting the need for affordable housing provision,

2) presents definitions of SRAs and provide an overview of their functioning,

3) makes an attempt to evaluate the possibility to use the tool to expand the existing social housing stock.

\section{Results}

\subsection{Diagnosis of the Housing Stock in Poland}

A preliminary glance at comparative statistics shows that the housing situation in Poland is one of the worst in the European Union. One of the key dimensions in evaluating the housing stock is the number of dwellings per 1000 inhabitants - in 2013 the number was approx. 360 units, which placed the country at the very bottom of the rank. According to the most recent population census (as of 2011), the current shortage of apartments measured by means of actual population is estimated at 76,5 thousand units. However, other studies suggest that the housing shortage amounts to $1,5 \mathrm{mln}$ units. (NIK, 2012) The estimated number of new apartments that should be delivered has its roots in the unfavorable qualitative structure of the existing stock Herbst (2013) estimates the substandard stock for demolition at $1 \mathrm{mln}$ units, while the NIK's report points at 200 thousand units. (NIK, 2012)

As for the age of the housing stock structure - approximately $20 \%$ of the dwellings were built in the pre-war period, while over 50\% of the units were delivered in the years 1945-1988. (GUS, 2013) The post-war housing construction covers a significant proportion of large-panel buildings that are characterized by: 1) small dwellings (the most commonly offered housing area for a four person household was less than $50 \mathrm{~m}^{2}$, with two bedrooms and no living room), 2) standardized layout of dwellings (small kitchen or kitchenette, no dining space or utility room), and 3) low technical standard: poor insulation, bad sound insulation, no summer shades for windows, substandard sanitary systems and heating utilities. Moreover, the high-rise multitenant buildings pose problems with regard to town-planning as they destruct the existing urban context, and are very often located in small settlements or on areas with meager public transport infrastructure. (Kemeny \& Lowe, 1998) 
With regard to tenure, owner-occupation has traditionally been a dominant form: in 2013 more than $75 \%$ of the total housing stock was owned, out of which houses accounted for $57,2 \%$ and condominiums for $18,2 \% .16,2 \%$ of the overall housing was delivered onto the market by cooperatives, the remaining share was provided by social housing or other actors $(6,7 \%$ was rented out from the municipal stock, over $0,8 \%$ was owned by companies, $0,7 \%$ by the social housing associations known as TBS, and $0,2 \%$ by the State Treasury). (Housing Europe, 2015) It is noticeable that the most significant change occurred within the share of municipal housing and the stock owned by cooperatives. Before the economic transformation, the state owned approx. $30 \%$ of the overall housing stock. A similar, yet not that radical shift occurred in the case of cooperatives: in 2002 they owned 28,6\% of the stock (GUS, 2003), but the number diminished gradually due to changes in legal regulations that facilitated privatization processes. Moreover, it is critical to note that the overall production of new dwellings is on a rather low level, while the provision of affordable housing (categorized as "other") is considered severely insufficient (Fig. 1).

Figure 1: Dwellings completed in the years 1993-2015 according to tenure form

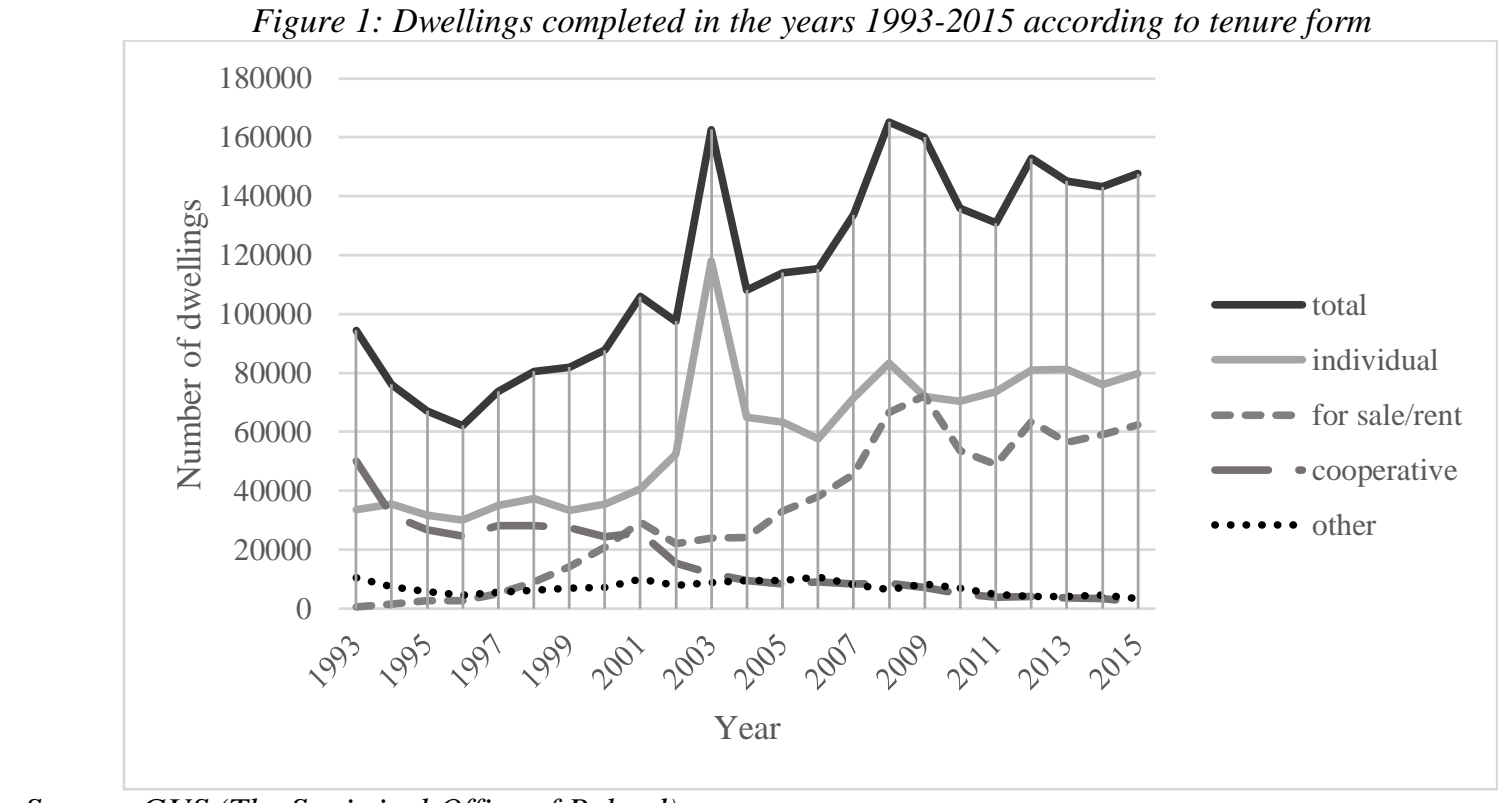

Source: GUS (The Statistical Office of Poland)

It is noteworthy that Poland ranks high in categories such as overcrowding of dwellings (44,2\% of households as opposed to the EU average of 16,9\%), and severe housing deprivation $(9,1 \%$ while the EU average was $5,1 \%)$. The statistical data on population in housing cost overburden is also worrying - almost $10 \%$ of all households spend more than $40 \%$ of their disposable income on housing. (Muzioł-Węcławowicz (2017)) Although the problem of mortgage loans does not seem to be the most acute in comparison to other EU countries, the global financial crisis led to a significant increase in the volume on non-performing loans. In its aftermath, some recommendations leading to more prudential practices and rigid lending conditions were introduced by the Polish Financial Supervisory Authority. Another challenge stems from the fact that numerous housing loans have been contracted in Swiss francs, and due to the substantial increases in the exchange rate of the currency at the beginning of 2015, approximately one million Poles are considered to be affected. (Herbst (2013))

\subsection{Renting vs. Other Tenure Forms}

As mentioned above, the dominant form of tenure in Poland is ownership. It is common of developing countries that the freehold rights to properties are most desirable. The reasons to it 
are manifold, e.g. inefficient legal systems, underdeveloped land-use, and the agricultural base of economic production. Moreover, this form of residency has been embedded in the postcommunist societies who had once been forced to relinquish the notion that housing should cater for the individual's needs - instead, it had been considered an egalitarian, collective, and public good. Not only are the socio-ideological factors crucial to understanding the proliferation of home ownership in Central and Eastern Europe, but so is the economic background - the precarious employment conditions, along with the dire predictions with regard to public spending on social security, pensions and welfare. Possession of dwelling gives a sense of financial stability in times of economic or political volatility, and at the institutional level it has actually become an imperative. (Zubrzycka-Czarnecka, 2015)

Assuming there are three basic tenure types in the Polish housing system, cooperatives form a sort of intermediate tenure; the other two being ownership and renting: both public and private. Once considered a close counterpart of owner-occupancy, cooperatives are now perceived by many as the relics of communism, and their significance and attractiveness have been gradually decreasing. Within the cooperative housing stock, two rights to dwellings can be distributed: the in rem proprietary right and the in personam tenancy right, yet in both cases the cooperative remains the owner of both the building and the dwellings. The fundamental difference between the two forms is the amount of the so-called construction input paid by the holder of the right, and the rights to the dwelling tenants can exercise. While the proprietary right can be alienated inter vivos, transferred mortis causa and be attachable in civil enforcement proceedings, neither of the privileges are ascribed to the in personam tenancy right. As from 1972 it was permissible under special conditions to convert a tenancy right into a proprietary right (Manko, 2015), while the latter could be converted into a form of ownership. Currently, over $83 \%$ out of 2,6 mln cooperative dwellings function similarly to condominiums, while a mere $16,7 \%$ constitute tenancy rights (i.e. rental cooperative rights). (Hegedus et al., 2014)

The third tenure form covers rental housing. It is estimated on the basis of the recent population census that over 2,2 mln households in Poland (i.e. 16,6\% of all households) rented flats in 2011- mainly from municipalities (more than $1 \mathrm{mln}$ households) or private owners $(0,6$ mln of households). (GUS, 2014) The three categories mentioned above occur in numerous forms as shown in Table 1.

Table 1: Households according to tenure type (2001)

\begin{tabular}{llll}
\hline Type & $\begin{array}{l}\text { Total } \\
\text { share in [\%] }\end{array}$ & City & Countryside \\
\hline Total & 100 & 100 & 100 \\
$\begin{array}{l}\text { Households with particular tenure type: } \\
\text { ownership }\end{array}$ & 55.3 & 43.4 & 80 \\
$\quad$ - of a building & 37.8 & 21.1 & 72.2 \\
$\quad$ of a flat & 17.6 & 22.3 & 7.8 \\
Cooperative & 16.1 & 23.4 & 0.8 \\
Cooperative in rem & 13.5 & 19.7 & 0.6 \\
Cooperative in personam & 2.6 & 3.7 & 0.3 \\
& & & \\
Rental apartments & 16.6 & 22 & 5.6 \\
$\quad$ owned by: & 4.2 & & 1.2 \\
individual persons & 0.5 & 5.7 & 0.7 \\
cooperatives & 7.6 & 10.4 & 1.7 \\
municipalities & 1.4 & 1.5 & 1.1 \\
the state & 1.4 & 1.6 & 0 \\
companies & 0.6 & 0.9 & 0.3 \\
TBS social housing organisations & 0.4 & 0.4 & \\
other actors & & &
\end{tabular}




\begin{tabular}{llll}
\hline Type & $\begin{array}{l}\text { Total } \\
\text { share in [\%] }\end{array}$ & City & Countryside \\
\hline not identified & 0.6 & 0.8 & 0.1 \\
subletting & 0.3 & 0.3 & 0.1 \\
sharing housing to kinship & 9.5 & 7.9 & 12.6 \\
other & 0.5 & 0.5 & 0.4 \\
not identified & 1.8 & 2.4 & 0.4 \\
\hline Own elaboration based on GUS (2014) & & &
\end{tabular}

Currently, there are several rental options available in Poland: 1) dwellings in the private stock, mostly in condominiums and cooperatives - subject to market rent, 2) municipal apartments usually with rent rates at 1-2\% of the replacement value, 3) dwellings in the private stock, in privately-owned buildings with rent lower than market rates (a unique Polish form called mieszkania kwaterunkowe), 4) dwellings provided by social housing associations called TBS with annual rent cap up to $4 \%$ of the replacement value, 5) dwellings provided by the Rental Housing Fund with rent levels slightly lower than market rates. It is noteworthy that over the past few years renting has gained more interest and acceptance as an alternative for many households. Stringent requirements for mortgage financing, insecurity on the labour market, unfavourable employment contracts along with limited economic growth perspectives have led to households being reluctant about getting into long-term debt. The traditional and symbolic need for ownership is thus gradually becoming less convincing particularly for young people starting professional careers, for whom mobility and liquidity rationale is becoming more prominent. One may even venture an opinion that policies and discourse have ceased to perceive freehold right to housing as the default position with renting for the households awaiting to become homeowners or those on the margins of society.

The positive social perception of renting and the growing interest in it are in line with economic theories stating that enlarging the rental stock is beneficial for both local and national housing markets. First of all, the rental sector is less vulnerable to economic trends than the owner-occupied sector, and the stability of the overall housing market depends on the size of the rental sector (Van der Heijden, 2013). If its share is considerable, the negative economic effects (e.g. problems with financing, legal changes) on the owner-occupied housing market affect only a limited number of households. Furthermore, a comparative OECD study suggests that the existence of a well-functioning rental market can help to reduce the volatility of house prices. (Andre, 2010)

Despite the general tendency, there are still many landlords reluctant to let their unoccupied dwellings. The reasons are manifold, insecurity of this tenure being the most crucial one. Many owners refrain from renting properties due to the strong tenant law, lengthy eviction procedures, risk of demolition, or time-consuming formalities. If these hazards were ameliorated, they would free up their vacant dwellings into the market.

\subsection{Social Rental Agencies}

The need for affordable housing today is double as high as the total annual housing production in Poland, and a hundred times higher than the total annual housing production of municipalities and TBSes. (Muzioł-Węcławowicz, 2017) Just to visualize the shortage, below we present the chart depicting the number of people who filed for social housing out of the municipal stock belonging to Poznan city ( $5^{\text {th }}$ city in Poland with respect to population $-541,6$ thousand inhabitants, $8^{\text {th }}$ according to area). The number of applicants considering their housing situation bad is collated with the number of applicants who managed to fulfil the stringent 
allocation criteria ${ }^{1}$ to be signed up on the waiting list, the number of those who ranked highest on the list, and finally, those who succeeded in entering housing contracts (Fig. 2).

Figure 2: Applications for social housing in Poznań vs. contracts signed by the city of Poznań in the years 2012-2016

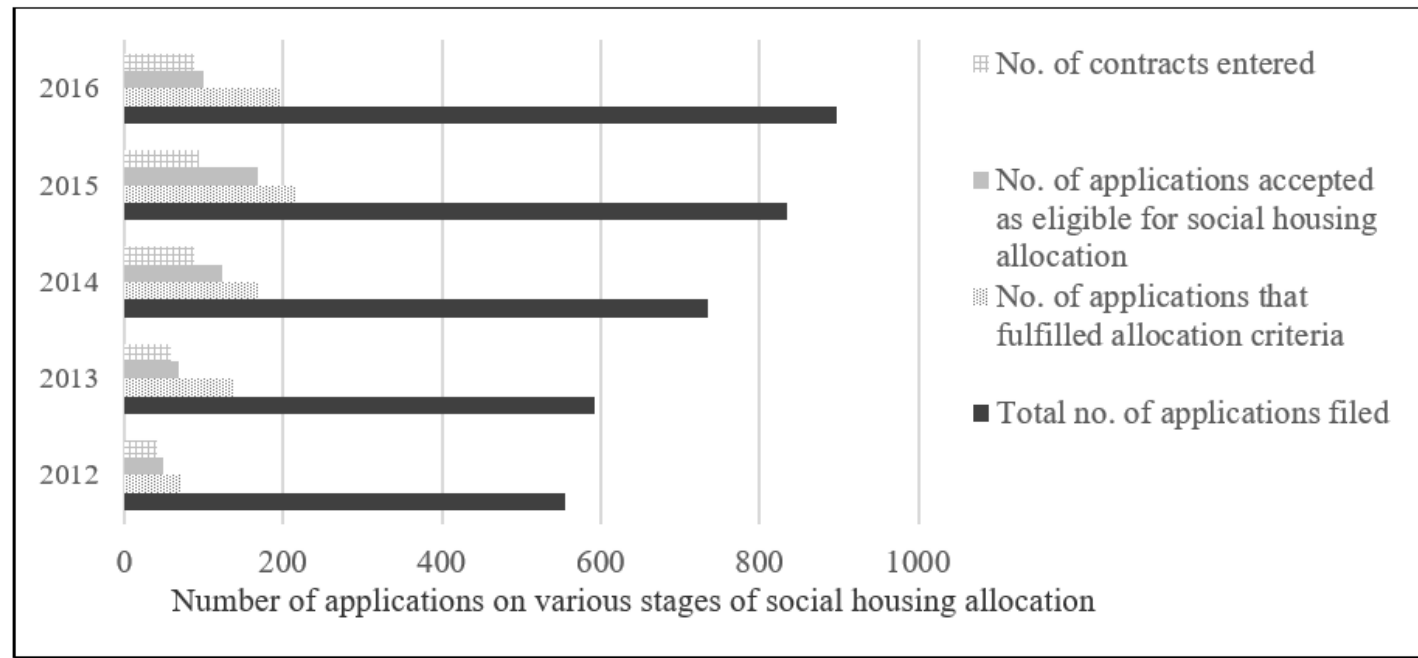

Source: Own elaboration based on information obtained from the company managing the public housing stock in Poznań city (ZKZL and BSL)

The picture is worrying, yet does not diverge from the overall housing situation in major Polish cities. It provokes the search for additional solutions to extend the stock of affordable housing. One of these solutions could be using a part of private rental stocks for social housing, e.g. in the form of SRAs. (Rataj, 2013) It is difficult to find a standardized definition of SRAs in the EU, yet the differences in understanding the concept across Europe are rather minor. FEANTSA (2012) defines them as non-profit housing institutions that address the housing problems of poor and vulnerable people. The organisation views SRAs as tools for socializing the private rental sector by withdrawing the management of private rented housing from the mechanisms of the free market and replacing it with social management. Mullins and Sacranie (2017) emphasize that they have been developed as an alternative tenure for low income households and those unable to access home ownership, while according to Rugg (2011) SRAs offer a next-best alternative to social housing in the context of shrinking public affordable housing sector. De Decker (2012) highlights that SRAs offer much more than housing assistance in terms of letting and maintenance - they also provide social support in solving problems or redirecting to proper advisory bodies. However, Mullins and Sacranie (2017) argue that most of the current literature on SRAs takes the form of pragmatic guides which are predominantly concerned with process, start up and viability. Less interest is attached to the outcomes and experience of tenants and landlords. This is a critical gap as the success of SRAs to a large extent depends on convincing reluctant landlords to join SRAs.

There is a wide range of motivations and rationale behind SRAs. Some of the most commonly named objectives involve:

- increasing the volume of the stock available for vulnerable households,

- improving the quality of housing in the lower end of the private rental sector,

- providing cost effective housing at a decent standard,

${ }^{1}$ In case of Poznań municipality, the criteria are set to be income, confirmed residence in Poznań city, and being put on the so-called "Mayoral list" - the waiting list approved by the city mayor, who can add to the list people in acute housing need. 
- providing housing at an affordable rent,

- providing more support than letting agents,

- providing housing with special support for tenants,

- giving tenants more choice and flexibility,

- promoting the idea of tenant participation,

- creating a risk-sharing financial model, where the cost and risk of social housing is shared between the landlord, the local SRA, the municipality (or a dedicated risk fund), and the tenants (FEANTSA, 2012; Mullins and Sacranie, 2017; Hegedus et al., 2014).

An important question remains in the trade-off, governing SRAs functioning - they are supposed to act in the public interest by assisting vulnerable tenants, but at the same time they need to adopt a commercial approach in order to be able to self-finance their activities. Such dichotomy is specific of many modern social enterprises that (to different extents) adopt entrepreneurial strategies to fulfil their objectives (versus traditional 'bureaucratic' or 'management-oriented' behaviour). (Czischke, 2012; Lennartz et al., 2012; Llop, 2016; Tang et al., 2017; Gruis \& Priemus, 2008; Haworth \& Manzi, 1999) SRAs generate income from the margin between rent and maintenance costs, and optionally from extra services. There is a serious threat that maintenance costs will be much higher than average due to the age and relatively lower quality of SLAs' stock.

\section{Discussion}

The offer of SLAs may differ from country to country, but in each case the key service is leasing dwellings in order to sublet them at an affordable rent to tenants with low-incomes. They search for owners willing to contribute with their dwellings, select tenants and guarantee payment of rent and maintenance of the physical quality of the housing. Because the guarantee of the landlord's revenue spans a long period of time (e.g. in Belgium over 9 years), SRAs have a good competitive edge enabling successful negotiations with landlords. To incentivise them, SRAs take responsibility for renovations as well as solve administrative and management issues. These include making a property inventory, registration of the rental contract, processing of deposits, collection of rent, fire insurance, real estate tax and avoiding the deterioration of the physical quality of the dwelling. Thus the practicalities of letting are transferred from the landlord to the agency (FEANTSA, 2012; Norris \& Coates, 2010)

Beside the basic task of letting, SRAs may also offer tenant support services, e.g. training households in cost-effective usage of housing, support with administrative problems, addiction services, coaching, helping in job search or linking to welfare services.

Another underlying question is the ideal tenant mix, i.e. who should gain access to the stock operated by SLAs. As for the tenant selection, SRAs usually operate within the same framework as social housing providers. Likewise, they set access priorities and allocation criteria. These criteria usually encompass financial situation (income), eligibility to social housing (need), social status (vulnerability), as well as preferences of entities engaged (choice). Again, the trade-off between commercial and social goals occurs as it is beneficial for the agency to allocate to least risky tenants, yet most socially efficient if the most vulnerable groups are housed. Therefore, it is a common practice in foreign countries to statutory reserve part of the stock for the most "precarious" tenants. (Boelhouwer et al., 1997)

SRAs come in various organizational forms and funding models. The choice depends on goals set in relation to local housing conditions, institutional costs of running a particular business type, as well as housing actors involved. They may be organized as commercial law companies or non-profit organizations. Experts emphasize, however, that in Polish conditions, 
it would be advisable to establish such agencies as independent bodies, not incorporated in the local self-government structures. Only then would SRAs have the freedom to realize statutory tasks, and be able to gain recognition and trust on the local market. If included in the structure, conflicts of interest could occur, such as lowering financial credibility of local self-governments by applying for bank loans. (Muzioł-Węcławowicz, 2017)

Presumably, the most important feature of SRAs is social justice embedded in the concept. Social advantages of the model encompass: 1) readiness for quick housing assistance (due to the fact that the agency uses existing housing stock and there is no construction process involved), 2) apartments rented by SAN are spatially dispersed, which prevents stigmatization and social exclusion due to the high concentration of vulnerable groups, 3) assisting tenants in solving housing and other problems. FEANTSA (2012) emphasizes that SRAs respond to an unmet social need - the need for integrated housing and support services for people facing housing exclusion. As these problems are not being addressed by the market, they fill a gap in the provision of affordable, decent and sustainable rental housing for people in housing need.

The biggest concern with respect to functioning of SRAs is caused by financial issues. Foreign literature often emphasizes that the main income source for SRAs should be the surplus after deduction of maintenance and organizational costs from rental income. (Rugg, 2011; FEANTSA, 2012) Contrary conclusions emerge from Polish studies. Muzioł-Węcławowicz (2017) argues that "SRAs by definition generate deficit" as the rent obtained will be lower than the one paid to the landlord. Realistic estimation of private landlords' willingness to accept lower rents oscillates around 80-90\% of market rents. On the other hand, it is assumed that the most vulnerable households cannot afford to pay more than 50-60\% of market rates. (MuziolWęcławowicz, 2017) Another concern is rent arrears. Looking at the statistics, it appears to be more than justified. In 2013, the percentage of apartments with tenants in rent arrears was as follows:

- in social housing owned by municipalities: $41 \%$,

- in the stock owned directly by the state: $29 \%$,

- in social housing associations TBS: $24 \%$,

- in housing provided by companies: $31 \%$,

- in private housing associations: $18 \%$. (GUS, 2014)

Therefore, special public or private resources must be secured for compensating SRAs for budget deficit due to the target group's vulnerability. (Cyran, 2015; Szarfenberg, 2016) The author suggests that additional financing could be obtained from: 1) extra services, 2) private donations, 3) public subsidies, and 4) repayable assistance.

\section{Conclusions}

It is a common practice, also in Poland, to engage private entities into realization of public tasks. Reaching for private support stems from constant deficit of public finance on one hand, and higher effectiveness of the private sector on the other hand. (Muzioł-Węcławowicz, 2017) There is a special formula to finance such projects, called private-public partnership, but it has not been used in the context of using the existing private stock to support social housing. Social housing in Poland is perceived as a safety net or emergency housing - it is mainly publicly owned, managed under a rent control regime and allocated administratively to households according to social and economic criteria. It seems to be irresponsive to innovations offered in the most developed European countries. One example of the obsolescence of the system is social housing allocation - while in the Netherlands social housing actors have been experimenting since 1990s with optimizing it (Delft system, KAN experiment, POL model (e.g. 
Van Daalen \& Van der Land, 2008; Andersson \& Magnusson, 2014), Polish municipalities stick to the traditional administrative housing distribution. Therefore, the author does not believe that SRAs will be implemented eagerly and quickly by the Polish local selfgovernments. The only possible way for SRAs to come into play and act effectively is being popularized and developed by non-profit organizations. Only after they will have gained trust and a reputation for good quality and results, will municipalities consider developing such institutions within their structures. Despite the struggle Habitat for Humanity Poland takes to convince local authorities that it is cheaper to subsidize SRAs than pay evicted tenants compensations for undelivered municipal flats, many for sure will not be willing to accept the financial burden of SRA's functioning. It is vital to search for new ways of providing rental apartments for vulnerable households, and SRAs appear to be an appropriate and effective tool for that. Not only do they help in better usage of the rental stock and solving vulnerable tenants' problems with accessing housing, but they also contribute to social mix policy. Introducing SRAs into the Polish housing policy would contribute to extending the affordable housing stock.

\section{Acknowledgment}

The preliminary version of the research was presented within ENHR conference in Tirana, Albania 2017. Some information applied in the process of preparation of the paper was obtained while conducting the research project "Social housing and its role in satisfying housing needs of indigent households in Poland" financed by the National Science Centre (2014/13/N/HS4/02100).

\section{References}

Andersson, R. \& Magnusson, T.L. (2014). Segregation, gentrification, and residualisation: from public housing to market-driven housing allocation in inner city Stockholm. International Journal of Housing Policy, 4, 3-21.

Andre, C. (2010). A bird's eye view of OECD housing markets. OECD Economics Department Working Papers, no. 746, OECD Publishing.

Apanowicz, J. (2003). Metodologia nauk. Torun, Poland: Wyd. Dom Organizatora.

Boelhouwer, P., van der Heijden, H. \& van de Ven, B. (1997). Management of social rented housing in western europe. Housing Studies, 12(4), 509-529.

Christophers, B. (2013). A monstrous hybrid: The political economy of housing in the early Twenty-first Century Sweden, New Political Economy, 18, 885-901.

Cyran, R. (2015). Analiza, w której rozważone zostaną możliwości wdrożenia społecznych agencji najmu ze względu na potencjał prywatnego rynku najmu. Habitat for Humanity, Warsaw, Poland.

Czischke, D. (2012). Conceptualizing social enterprise in housing organizations. Housing Studies, 27, 418-437.

De Decker, P. (2012). Social rental agencies: An innovative housing-led response to homelessness, FEANTSA.

De Decker P. (2002) On the Genesis of Social Rental Agencies in Belgium, Urban Studies, 39(2), $297-326$.

De Decker, P. \& Pannecoucke, I. (2004). The creation of the incapable social tenant in Flanders. Journal of Housing and the Built Environment, 19(3), 293-309.

FEANTSA (2012). Good practice briefing - social rental agencies: An innovative housing-led response to homelessness, Pascal de Decker and FEANTSA Working Groups. Belgium: FEANTSA.

Gruis, V. \& Priemus, H. (2008). European competition policy and national housing policies: International implications of the Dutch case. Housing Studies, 23, 485-505.

GUS (2014). Gospodarka mieszkaniowa w 2013. Warsaw, Poland.

Harvey, D. (1969). Explanation in Geography. London, United Kingdom: Edward Arnold.

Haworth, A. \& Manzi, T. (1999). Managing the 'underclass': Interpreting the moral discourse of housing management. Urban Studies, 36, 153-165.

Heijden van der, H. (2013). West European housing systems in a comparative perspective. Sustainable Urban Areas. TU Delft. IOS Press. 
Hegedus, J., Horvath V. \& Somogyi, E. (2014). The potential of social rental agencies within social housing provision in post socialist countries: The case of Hungary. European Journal of Homelessness, 8(2), 41-67.

Herbst, I. (2013). Potrzeby mieszkaniowe w Polsce. Dostęp do mieszkania w kontekście polityki prorodzinnej. Raport dla Kancelarii Prezydenta RP.

Holmqvist, E. \& Turner, L.M. (2014). Swedish welfare state and housing markets: under economic and political pressure. Housing and the Built Environment, 29, 237-254.

Housing Europe (2015). The state of housing in the EU 2015, the European Federation for public, cooperative and social housing, Bruksela, Belgium.

Kemeny, J. \& Lowe, S. (1998). Schools of comparative housing research: From convergence to divergence. Housing Studies, 13(2), 161-76.

Lennartz, C., Haffner, M. \& Oxley, M. (2012). Competition between social and market renting: a theoretical application of the structure-conduct-performance paradigm. Journal of Housing and the Built Environment, 27, 453-471.

Lind, H. (2001). Rent regulation: A conceptual and comparative analysis. International Journal of Housing Policy, 1(1), 41-57.

Lind, H. (2016). Atkomliga bostäder. SNS Förlag, Stockholm.

Lis, P. (2006). Społeczna polityka mieszkaniowa. Rocznik Ostrowskiego Towarzystwa Naukowego, 1/2006, Ostrów Wielkopolski.

Llop, N.L. (2016). Social housing management models in Spain. Revista Catalana de Dret Públic, 52, 115-128.

Lowe, S. \& Tsenkova S. (2003). Housing change in east and central Europe: Integration or fragmentation? Routledge, London.

Lux, M. (2013). Private and social: Contradiction or coherence? In habitat for humanity Hungary. Social Housing in the Context of the Rental Sector in Visegrad Countries. Budapest, Hungary.

Lux, M. (2016). Public housing in the post-socialist states of central and Eastern Europe: Decline and an Open Future, ETH Forum Wohnungsbau 2016. [Online]. Available: http://www.wohnforum.arch.ethz.ch /sites/default/files/tagungen/tagungsbericht_lux.pdf.

Malpass, P. (2008). Housing and the new welfare state: Wobbly pillar or cornerstone? Housing Studies, 23, 119.

Manko, R. (2015). The cooperative member's proprietary right to an apartment: A legal survival of the period of actually existing socialism in Polish private law. Zeszyty Prawnicze, 15, 4.

Mieszkania - National Census (2002). GUS, 01.08.2003.

Mieszkania - National population and housing census (2013). GUS, 29.05.2013.

Mullins, D. \& Sacranie, H. (2017). Social lettings agencies in the west midlands: Literature review and typology. Housing and Communities Research, University of Birmingham.

Muzioł-Węcławowicz, A. (2017). Społeczna agencja najmu. Dokument strategiczny, Habitat for Humanity Poland, Warsaw, Poland.

Narodowy Bank Polski (2016). Raport o sytuacji na rynku nieruchomości mieszkaniowych i komercyjnych w Polsce w 2015, Warsaw, Poland.

NIK (Supreme Audit Office) (2012). NIK o polityce mieszkaniowej. [Online]. Available: https://www.nik.gov.pl/aktualnosci/nik-o-polityce-mieszkaniowej.html.

Norris, M. \& Coates, D. (2010). Private sector provision of social housing: An assessment of recent irish experiments. Public Money \& Management, 30(1), 19-26.

Priemus, H. (1997). Growth and stagnation in social housing: What is 'social' in the social rented sector? Housing Studies, 12(4), 549-560.

Przymenski, A. \& Oliwa-Ciesielska, M. (2014). Publiczna pomoc mieszkaniowa a demarginalizacja społeczna ludności ubogiej. Poznań, Poland: Wydawnictwo Uniwersytetu Ekonomicznego w Poznaniu.

Rataj, Z. (2013). Osiedle socjalne Darzybór w Poznaniu — założenia a realizacja, Praca Socjalna, 6, 81-95.

Rugg, J. (2011). Local lettings agencies: a good practice guide. Providing access to the private rented sector while generating income. Crisis, Ethical Enterprise and Employment, 3.

Soaita, A. M. (2015). The meaning of home in Romania: Views from urban owner-occupiers. Journal of Housing and the Built Environment, 30(1), 69-85.

Strączkowski, Ł \& Suszynska, K. (2012). Housing situation of young married couples in the light of the local housing market research. Actual Problems of Economics, 7, 209-220.

Szarfenberg, R. (2016). Docelowy model społecznej agencji najmu. Habitat for Humanity Poland, Warsaw, Poland.

Tang, C.P.Y., Oxley, M. \& Mekic, D. (2017). Meeting commercial and social goals: institutional investment in the housing association sector. Housing Studies, 32, 411-427. 
Tsenkova, S. (2004). The social housing sector in Prague and Warsaw: Trends and future prospects. Geojournal, 79(4), 433-447.

Van Daalen, G. \& Van Der Land, M. (2008). Next steps in choice-based letting in the Dutch social housing sector. European Journal of Housing Policy, 8(3), 317-328.

Whitehead, C.M.E. \& Scanlon, K. (2007). Social housing in Europe. London, United Kingdom: London School of Economics and Political Sciences.

Zubrzycka-Czarnecka, A. (2015). Społeczne Agencje Najmu (AIS/SVK) w Belgii - innowacja służąca przeciwdziałaniu "prekaryzacji mieszkaniowej". Habitat for Humanity Poland, Warsaw, Poland.

Żołędowski, C., Ołdak, M. \& Szarfenberg, R. (2016). Społeczne agencje najmu jako instrument polityki mieszkaniowej. Przykłady europejskie i implementacja w Polsce, Instytut Polityki Społecznej Uniwersytetu Warszawskiego, Warsaw, Poland. 